\title{
Organochlorine and organophosphorus pesticide concentrations in water, sediment, and selected organisms in Lake Naivasha (Kenya)
}

\author{
S. M. Gitahi ${ }^{1, *}$, D. M. Harper ${ }^{2}$, S. M. Muchiri ${ }^{3}$, M. P. Tole ${ }^{4} \&$ R. N. Ng'ang'a ${ }^{5}$ \\ ${ }^{1}$ Lake Naivasha Riparian Association, P.O. Box 1011, Naivasha, Kenya, \\ ${ }^{2}$ Department of Biology, University of Leicester, Leicester LE1 7RH, U.K. \\ ${ }^{3}$ Department of Fisheries, Moi University, Box 3900, Eldoret, Kenya \\ ${ }^{4}$ School of Environmental Studies, Moi University, P.O. Box 3900, Eldoret, Kenya \\ ${ }^{5}$ Kenya Plant Health Inspectorate Service, P.O. Box 49592, Nairobi, Kenya \\ $\left({ }^{*}\right.$ Author for correspondence)
}

Key words: organochlorinated and organophosphorus pesticide residues, bioaccumulation, Procambarus clarkii, Micropterus salmoides

\begin{abstract}
Water, sediment, red swamp crayfish (Procambarus clarkii) and black bass (Micropterus salmoides) from Lake Naivasha were analyzed for selected organochlorine and organophosphorus pesticide residues. The mean $p, p$ 'DDT, $o, p$ '-DDT and $p, p$ '-DDE residue levels recorded in black bass (28.3 ( \pm 30.0$), 34.2( \pm 54.0)$ and $16.1( \pm 16.1)$ $\mu \mathrm{g} \mathrm{kg}^{-1}$, respectively) and crayfish $\left(4.6( \pm 5.1), 3.2( \pm 2.8)\right.$, and $1.4( \pm 1.1) \mu \mathrm{g} \mathrm{kg}^{-1}$, respectively), were higher than previously recorded. This indicated recent usage of technical DDT in the lake's catchment. Levels of $p, p$ 'DDT, higher than those of $p, p^{\prime}$-DDE further emphasized this. Mean lindane, dieldrin, $\beta$-endosulfan and aldrin concentrations in black bass were $100.5,34.6,21.6$ and $16.7 \mu \mathrm{g} \mathrm{kg}^{-1}$, respectively. The same residues were detected at lower concentrations in crayfish at 2.0, 2.0, 2.0 and $1.9 \mu \mathrm{g} \mathrm{kg}^{-1}$, respectively. The higher fat content $(3.7 \pm 2.7 \% \mathrm{SD})$ in black bass (compared to $0.6 \pm 0.3 \%$ in crayfish) accounted for the significantly higher residue concentrations in black bass. Organophosphate pesticides were the most commonly used pesticides in the lake's catchment, but none was detected in any of the samples. The results indicate that there is need for further work to identify sources and fate of pesticide contaminants, as well as to improve monitoring of pesticide use throughout the catchment.
\end{abstract}

\section{Introduction}

Pesticide use has resulted in acute and chronic ecological damage, either by direct injury to non-target organisms such as birds and fish, or by indirect effects such as elimination of natural enemies. Pesticides are a singular form of environmental hazard in that they are actually designed to harm living things. Many organochlorine compounds are very persistent in the environment and have a tendency to bioaccumulate significantly through food chains (UNEP, 1993). Organophosphates have several advantages over other types of pesticides, including high acute toxicity to target organisms, but they are not persistent in the environment as are organochlorines, as they decompose to non-toxic products. However, their acute toxicity is of concern.

Aquatic environments are particularly affected because pesticides applied to land-based agriculture systems are eventually carried into water bodies through surface runoff, rivers, and groundwater flow. Therefore, chronic and acute effects of pesticide pollution and bioaccumulation in aquatic flora and fauna are more severe.

Due to the undesirable effects on environmental quality and animal health, the production and usage of organochlorine compounds was banned or severely restricted during the 1970s and 1980s in most developed countries. However, the demand for organochlorine pesticides has been increasing in some developing 
countries in Africa, Latin America and Asia (Tanabe et al., 1993). There has been widespread use of pesticides in Kenya in the last four decades because agriculture has been the mainstay of Kenya's economy. Organochlorines have been extensively used and particularly, DDT and endosulfan for the control of maize and cotton pests (Munga, 1990). Lindane, dieldrin, aldrin, endrin and heptachlor have also had wide usage in Kenya, which has made their presence ubiquitous in the environment (Wandiga, 1996).

Lake Naivasha, Kenya's second largest freshwater lake, is a valuable national centre for fishing, agriculture and tourism. The lake is also important for biodiversity and received RAMSAR recognition in 1995. But in recent years the lake has faced intensified horticulture/floriculture development for the export market, and this is thought to contribute pesticide pollution into the lake. The purpose of this study was to establish the extent of organochlorine and organophosphate insecticide contamination in lake Naivasha.

\section{Materials and methods}

\section{Pesticide use survey}

Information on pesticides commonly used in the lake Naivasha basin was obtained through visits to the area Public Health office and horticultural companies, as well as to farmers' shops in different townships in the lake's catchment.

\section{Field sampling}

Sampling wascarried out at five selected sites around Lake Naivasha between August 1997 and January 1998. Black bass (Micropterus salmoides Lacepede) samples were collected by gill nets, while crayfish (Procambarus clarkii Girard) samples were collected from the littoral water hyacinth zone using traps and sweep-nets, and grouped by carapace length. Crayfish muscle was extracted by peeling. The black bass and crayfish muscle samples were weighed and immediately frozen prior to analysis. Sediment samples obtained by use of a core sampler, lake water samples, and water samples from the main river, the Malewa, were also collected. Water samples were stored in glass bottles at $2-4^{\circ} \mathrm{C}$, and sediment at -5 to $-10^{\circ} \mathrm{C}$, awaiting analysis. All the samples were transported to the laboratories in coolboxes with freezer packs.
The samples were analysed for the organochlorines lindane $(\gamma-\mathrm{HCH}$, hexachlorocyclohexane), dieldrin, aldrin, $p, p^{\prime}$-DDT, $o, p^{\prime}$-DDT, $p, p^{\prime}$-DDE and $\beta$ endosulfan, as well as for the organophosphates diazinon, malathion and parathion.

\section{Reagents}

All solvents ( $n$-hexane, acetone, dichloromethane, diethyl ether) as well as other analytical material used (anhydrous sodium chloride, Florisil) were of analytical grade quality (Merck, NJ, USA), double-distilled to ensure purity. Florisil and individual pesticide standards were available at the Kenya Agricultural Research Institute laboratories, Nairobi.

\section{Extraction and cleanup}

Extraction and cleanup followed previously described protocol (NRI, 1991). Black bass liver or crayfish muscle was dried using anhydrous sodium sulphate, and individually extracted using 3:1 hexane:acetone. An aliquot of each extract was evaporated to dryness to calculate the tissue fat content. Anhydrous sodium sulphate was added to sediment samples to speed dessication. The samples were then individually soxhlet extracted, using 1:1 acetone:hexane. Water samples were extracted using dichloromethane. At this stage extracts in hexane could be injected for organophosphate quantification. The extracts were cleaned up with Florisil, using 6 and 15\% diethyl ether in hexane as the elution mixture. The final pesticide extract was obtained in $5 \mathrm{ml}$ of hexane.

\section{Chromatographic analyses}

Gas chromatographic analyses were carried out using Varian 3400 series GLC, fitted with an electron capture detector (ECD) for organochlorines and a nitrogen-phosphorus detector (NPD) for organophosphates. Two $\mu \mathrm{l}$ aliquots of the pesticide extracts and a pesticide standard mixture were injected into the GLC for analysis. A DB-5 capillary column $(30 \mathrm{~m}, 0.2 \mathrm{~mm}$ i.d.) was used to separate organochlorine insecticides, while for organophosphates a DB-5 megabore capillary column ( $15 \mathrm{~m}, 0.53 \mathrm{~mm}$ i.d.) was employed (both J\&W Scientific, Folsom, CA, USA). The carrier gas was nitrogen. 


\section{Results}

Most commonly used pesticides

The most commonly used pesticides (excluding herbicides) in the Lake Naivasha basin were organophosphates, carbamates, and pyrethroids, in that order, with very few organochlorines (Table 1).

\section{Recovered pesticide residues}

All the organochlorines were detected in the black bass and crayfish samples in varying concentrations and frequencies of occurrence (Tables 2 and 3). None of the pesticide residues were detected in sediment samples, or in the lake and river water samples. No organophosphates were detected in any of the samples.

\section{Fat content}

The mean fat content was $3.73 \%( \pm 2.71 \% \mathrm{SD})$ and $0.56 \%( \pm 0.27 \% \mathrm{SD})$ in black bass liver and crayfish muscle, respectively. No correlation was observed between size and the corresponding fat content in either black bass or crayfish $\left(r^{2}<0.2\right)$.

\section{The influence of size}

No correlation between the concentration of contaminants and size was observed in either black bass or crayfish from all stations. The relationship between total weight and lindane concentration is shown for both species in Figure 1.

\section{Discussion}

\section{The influence of size}

Munga's (1990) study on fish from the Hola Irrigation Scheme strongly indicated that organochlorine pesticide levels were dependent on the amount of fat in fish, caused by concomitant changes in the total lipid content as organisms increase in age. The lack of correlation between residue and size in the present study was probably due to the lack of correlation between fat content and black bass or crayfish size.

\section{Organochlorines}

While $p, p$ '-DDT is the functional compound used, its conversion in the environment produces the metabolite $p, p$ 'DDE (Kanja et al., 1986; Mugambi et al., 1989; Pastor et al., 1996). Environmental conversion of DDT to the more persistent DDE may result in samples containing predominantly DDE. In the present study mean $p, p$ '-DDT levels were slightly higher than mean $p, p$-DDE levels in both black bass and crayfish. This illustrated a fairly recent exposure to functional DDT.

Today the use of DDT in Kenya is banned, except in the control of mosquitoes by public health authorities (PCPB, 1998). DDT has in the past been detected in Kenya in fish from different areas. Koeman et al. (1972) and Greichus et al. (1978) reported very low levels of organochlorine residues in Tilapia grahami from Lake Nakuru, while Lincer et al. (1981), in a study of DDT contamination in some Rift Valley lakes, reported DDT residue levels of below $1 \mathrm{ppm}$ in $T$. grahami from Lake Nakuru and in T. nilotica, Clarias mossambicus, Barbus gregorii and Labeo cylindricus from Lake Baringo. Mitema \& Gitau (1989) found DDT to range from $2 \mu \mathrm{g} \mathrm{kg}^{-1}$ (ppb) to $4.51 \mathrm{mg} \mathrm{kg}^{-1}$ (ppm) in the fillet of Nile perch from Lake Victoria. Mugachia et al. (1992a,b), in a study on catfish, common carp and tilapia from the Athi River estuary and Masinga Dam, found mean levels of $p, p^{\prime}$-DDE, $o, p^{\prime}$ DDT and $p, p^{\prime}$-DDT of below 1 ppm. Munga (1990) found DDT to be $0.13,0.92$ and $0.38 \mathrm{mg} \mathrm{kg}^{-1}$ (ppm) wet mass in the muscle, liver and eggs, respectively, in Labeo gregorii from the Hola Irrigation Scheme.

Lincer et al. (1981) reported undetectable to low levels of $p, p^{\prime}$-DDE in fish from Lake Naivasha. DDT residues were found to be 0.001 and $0.003 \mathrm{mg} \mathrm{kg}^{-1}$ in Tilapia spirulus niger and Micropterus salmoides, respectively. These authors however, found levels of DDE in the white pelican of Naivasha to have doubled since 1970, indicating an increase in organochlorine contamination of the system. A positive bioaccumulation of $p, p$-DDE in the food-chains of lakes Naivasha, Baringo and Nakuru was found (Lincer et al., op. cit.). Frank et al. (1977) studying organochlorine residues in Kenyan birds of prey, reported that most raptors from agricultural areas (including Naivasha) contained residues of DDT metabolites, whereas those from non-agricultural areas did not contain detectable levels of any organochlorines. The most widespread contaminant was $p, p^{\prime}$-DDE whose concentration ranged from $<0.01$ to $40 \mathrm{mg} \mathrm{kg}^{-1}$.

The DDT residue levels in the present study are higher than those reported previously in fish from Lake Naivasha. Wandiga (1996) has shown that organochlorine pesticides have a shorter half-life in the tropics than in temperate climates, and suggests that 
Table 1. Pesticides most commonly used in intensive horticulture/floriculture around Lake Naivasha and in small-scale agriculture in the lake's catchment

\begin{tabular}{|c|c|c|c|c|c|}
\hline \multicolumn{3}{|c|}{ Intensive horticulture/ floriculture } & \multicolumn{3}{|c|}{ Small-scale shops in catchment } \\
\hline Trade name & Common name & Family & Trade name & Common name & Family \\
\hline Lannate & Methomyl & Carbamoyloxime (I) & Triatix & Amitraz & Amidine \\
\hline Apollo & Clofentezine & Tetrazine (A) & Dimethoate & Dimethoate & Organophosphate \\
\hline Brigade & Bifenthrin & Pyrethroid (I) & Karate & $\begin{array}{l}\text { Lambda- } \\
\text { cyhalothrin }\end{array}$ & Pyrethroid \\
\hline Mitac & Amitraz & Amidine (I,A) & Diazinon & Diazinon & Organophosphate \\
\hline Nemacur & Fenamiphos & Organophosphate $(\mathrm{N})$ & Brigade & Bifenthrin & Pyrethroid \\
\hline Orthene & Acephate & Organophosphate $(\mathrm{A}, \mathrm{I})$ & Almatix & Amitraz & Amidine \\
\hline Pentac & Dienochlor & Organochlorine (A) & $\begin{array}{l}\text { Poultry louse } \\
\text { powder }\end{array}$ & Permethrin & Pyrethroid \\
\hline Thiodan & Endosulfan & Organochlorine (I) & Mboga dust & Fenitrothion & Organophosphate \\
\hline Cascade & Flufenoxuron & Benzoylurea (I) & Sevin & Carbaryl & Carbamate \\
\hline Dursban & Chlorpyrifos & Organophosphate $(\mathrm{A}, \mathrm{I})$ & Marshall & Carbosulfan & Carbamate \\
\hline Folimat & Omethoate & Organophosphate $(\mathrm{A}, \mathrm{I})$ & Py-grease & Pyrethrin & Pyrethroid \\
\hline Furadan & Carbofuran & Carbamate (I) & Diazol & Diazinon & Organophosphate \\
\hline Hostathion & Triazophos & $\begin{array}{l}\text { Organophosphate(I,A, } \\
\text { N) }\end{array}$ & Furadan & Carbofuran & Carbamate \\
\hline Mesurol & Methiocarb & Carbamate (A,I,M) & Taktik & Amitraz & Amidine \\
\hline Omite & Propargite & Sulfite (A) & & & \\
\hline Tedion & Tetradifon & Bridged-diphenyl (A) & & & \\
\hline Temik & Aldicarb & Carbamoyloxime (I) & & & \\
\hline Vydate & Oxamyl & Carbamoyloxime (I) & & & \\
\hline Kelthane & Pirimiphos-methyl & Organophosphate (I) & & & \\
\hline
\end{tabular}

I -Insecticide; A - Acaricide; N - Nematicide; $\mathrm{M}=$ Molluscicide.

Table 2. Mean, range and percent frequency of occurrence of organochlorine pesticide residue levels $\left(\mu \mathrm{g} \mathrm{kg}^{-1}\right)$ in blackbass from Lake Naivasha $^{a}$

\begin{tabular}{|c|c|c|c|c|c|c|c|}
\hline & $o, p^{\prime}$-DDT & $p, p$ '-DDT & $p, p^{\prime}-\mathrm{DDE}$ & Lindane & $\beta$-Endosulfan & Dieldrin & Aldrin \\
\hline $\begin{array}{l}\operatorname{Mean}^{b} \\
( \pm \mathrm{SD})\end{array}$ & $\begin{array}{r}34.2 \\
(54.0)\end{array}$ & $\begin{array}{r}28.3 \\
(30.0)\end{array}$ & $\begin{array}{l}16.1 \\
(16.1)\end{array}$ & $\begin{array}{l}100.5 \\
(266.0)\end{array}$ & $\begin{array}{r}21.6 \\
(30.5)\end{array}$ & $\begin{array}{r}34.6 \\
(56.0)\end{array}$ & $\begin{array}{l}16.7 \\
(18.8)\end{array}$ \\
\hline Minimum & 1.5 & 2.6 & 0.5 & 3.7 & 1.2 & 1.8 & 0.8 \\
\hline Maximum & 186.6 & 100.7 & 58.2 & 1595.9 & 161.8 & 265.8 & 70.7 \\
\hline $\begin{array}{l}\text { Positive }^{c} \\
\text { (\% frequency) }\end{array}$ & $\begin{array}{l}20 \\
(57.1 \%)\end{array}$ & $\begin{array}{l}27 \\
(77.1 \%)\end{array}$ & $\begin{array}{l}23 \\
(65.7 \%)\end{array}$ & $\begin{array}{l}35 \\
(100 \%)\end{array}$ & $\begin{array}{l}31 \\
(88.6 \%)\end{array}$ & $\begin{array}{l}25 \\
(71.4 \%)\end{array}$ & $\begin{array}{l}28 \\
(80.0 \%)\end{array}$ \\
\hline
\end{tabular}

a $0.2 \mu \mathrm{g} \mathrm{kg}^{-1}=$ lowest working concentration (below which residues could not be quantified).

${ }^{b}$ Residue levels given on wet weight basis. Mean was calculated for positive samples.

$c$ Total samples $=35$.

within 3-4 years much of it is already volatilised in tropical soils. This further suggests recent DDT application in the. Naivasha catchment.

Aldrin and dieldrin usage in Kenya is restricted only to termite control in the building industry (PCPB, 1998). Dieldrin is a functional pesticide, but it is also a persistent environmental metabolite of aldrin. Therefore use of aldrin contributes to dieldrin levels in a system (Mugambi et al., 1989). Dieldrin is the more persistent of the two. Therefore the current results indicate that aldrin has been in considerable use in the lake's catchment. The extent of aldrin use in Kenya has 
Table 3. Mean, range and frequency of occurrence of organochlorine pesticide residue levels $\left(\mu \mathrm{g} \mathrm{kg}^{-1}\right)$ in crayfish from Lake Naivasha ${ }^{a}$

\begin{tabular}{|c|c|c|c|c|c|c|c|}
\hline & $o, p^{\prime}$-DDT & $p, p^{\prime}$-DDT & $p, p^{\prime}-\mathrm{DDE}$ & Lindane & $\beta$-Endosulfan & Dieldrin & Aldrin \\
\hline Mean $^{b}$ & 3.2 & 4.6 & 1.4 & 2.0 & 2.0 & 2.0 & 1.9 \\
\hline$( \pm \mathrm{SD})$ & $(2.8)$ & $(5.1)$ & (1.1) & $(2.3)$ & (1.8) & $(2.5)$ & (1.6) \\
\hline Minimum & 0.5 & 1.1 & 0.3 & 0.2 & 0.3 & 0.4 & 0.1 \\
\hline Maximum & 11.9 & 25.0 & 4.2 & 10.4 & 7.5 & 11.1 & 6.1 \\
\hline Positive $^{c}$ & 30 & 22 & 34 & 29 & 23 & 22 & 27 \\
\hline (\% frequency) & $(85.7 \%)$ & $(62.9 \%)$ & $(97.1 \%)$ & $(82.9 \%)$ & $(65.7 \%)$ & $(62.9 \%)$ & $(77.1 \%)$ \\
\hline
\end{tabular}

${ }^{a} 0.2 \mu \mathrm{g} \mathrm{kg}^{-1}=$ lowest working concentration (below which residues could not be quantified).

${ }^{b}$ Residue levels given on wet weight basis. Mean was calculated for positive samples.

$c$ Total samples $=35$.

a.

Relationship between blackbass total weight

(g) and lindane concentration ( $u \mathrm{~g} / \mathrm{kg}$ )
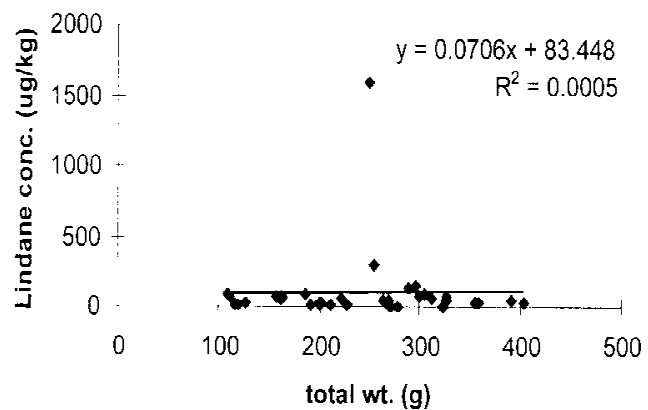

b.

Relationship between crayfish carapace length $(\mathrm{mm})$ and lindane concentration ( $u \mathrm{~g} / \mathrm{kg}$ )

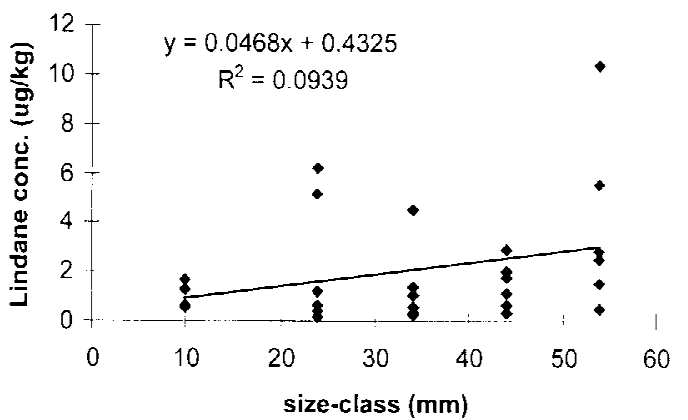

Figure 1. Relationship between size (black bass total weight (a) and crayfish carapace length (b) and lindane concentration $\left(\mu \mathrm{g} \mathrm{kg}^{-1}\right)$.

probably been much less than the use of DDT, but relatively high aldrin and dieldrin levels have been found in Kenyan human milk as compared to the corresponding levels in other countries (Kanja et al., 1986) and in domestic fowl eggs from central Kenya (Mugambi et al., 1989).

Most of the highest residue concentrations recorded in black bass and crayfish were those of lindane. Therefore lindane may be in significant use in the lake's catchment. Technical $\mathrm{HCH}$ is a widely used insecticide in Kenya but it also contains $\beta$ - $\mathrm{HCH}$ as a minor component (Kanja et al., 1986). Lindane in Kenya is restricted to use for seed dressing only. It was observed on the shelves of agricultural stores in the lake's catchment. The relatively biodegradable and less persistent nature of the $\mathrm{HCHs}$, and the fact that lindane is less persistent than $\beta$ - $\mathrm{HCH}$ (Tanabe et al., 1993) can only indicate either continuing, or recent, input into the lake of lindane. The present results are similar to previous findings in Kenya. Low lindane levels of 10-139 ppb were found in mother's milk (Kanja et al., 1986) and chicken eggs (10-100 ppb: Mugambi et al., 1989). Low lindane levels have also been reported in the liver and fillet of common carp, catfish and tilapia from the Tana River system, at 9-140 $\mu \mathrm{g} \mathrm{kg}^{-1}$ (Mugachia et al., 1992a,b).

$\beta$-Endosulfan levels in the present study are much higher than the levels reported by Munga (1990), of 0.01 and $0.05 \mu \mathrm{g} \mathrm{kg}^{-1}$ respectively, from Clarias gariepinus and Labeo gregorii in the Tana River. Use of endosulfan (Thiodan) has grown from the 1980s, as an alternative to DDT, especially in the country's cotton growing areas, because cotton pests had developed resistance to DDT (S.O. Wandiga, pers. comm.). It was evident that technical endosulfan was in considerable use in the Lake Naivasha catchment. 


\section{Organophosphates}

The most commonly used pesticides (excluding herbicides) in the L. Naivasha basin were organophosphates, carbamates, and pyrethroids, in that order, with relatively few organochlorines. The majority of these pesticides are registered in Kenya by the Pest Control Products Board (PCPB, 1998). However, none of the samples registered positive for diazinon, malathion or parathion. This is probably because of their relatively short half-lives, whereby they do not remain active in the environment for long (Lalah and Wandiga, 1996).

Lack of organophosphate residues in samples does not necessarily indicate lack of impact of organophosphate compounds on the environment. They may still impact on the aquatic system in the short term, before they break down to non-toxic products. However, while the fate in the aquatic system of organophosphate compounds is not clear, the most serious concern relating to the organophosphates is that they are still suspected to have serious toxicological impacts upon terrestrial wildlife and man. The vast majority of dead raptors sent to the Ornithology Department National Museums of Kenya, come from the Naivasha region. It is suspected that agrochemicals are the culprit because of the rapid expansion in horticultural practices in the region although analysis of the cadavers has not been carried out (Thomsett, pers. comm).

\section{Acknowledgements}

Financial support from both the KWS-Netherlands Wetlands Conservation and Research Training Programme and logistical help from the Earthwatch Lake Naivasha Research Project is gratefully acknowledged. We wish to thank the Kenya Agricultural Research Institute's National Agricultural Research Laboratories, for logistical and technical support.

\section{References}

Frank, L. G., R. M. Jackson, J. E. Cooper \& M. C. French, 1977. A survey of chlorinated hydrocarbon residues in Kenyan birds of prey. E. Afr. Wildl. J. 15: 295-304.
Greichus, Y. A., A. Greichus, B. D. Aman \& J. Hopcraft, 1978. Insecticides, polychlorinated biphenyls and metals in African lake ecosystems III, Lake Nakuru, Kenya. Bull. Environ. Contam. Toxicol. 19: 455

Kanja, L., J. U. Skaare, I. Nafstad, C. K. Maitai \& P. Lökken, 1986. Organochlorine pesticides in human milk from different areas of Kenya 1983-1985. J. Toxicol. Environ. Health 19: 449-464.

Koeman, J. H., J. H. Pennings, J. J. M. De Goeij, P. S. Tjioe, P. M. Olindo \& J. Hopcraft, 1972. A preliminary survey of the possible contamination of Lake Nakuru in Kenya with some metals and chlorinated hydrocarbons. J. Appl. Ecol. 9: 411.

Lalah, J. O. \& S. O. Wandiga, 1996. The persistence and fate of malathion residues in stored beans (Phaseolus vulgaris) and maize (Zea mays). Pestic. Sci. 46: 215-220.

Lincer, J. L., D. Zalkind, L. H. Brown, \& J. Hopcraft, 1981. Organochlorine residues in Kenya's Rift Valley lakes. J. Appl. Ecol. 9: 411.

Mitema, E. S. \& F. K. Gitau, 1990. Organochlorine residues in fish from Lake Victoria in Kenya. Afr. J. Ecol. 28: 234.

Mugachia, J. C., L. Kanja \& F. Gitau, 1992a. Organochlorine pesticide residues in fish from Lake Naivasha and Tana River, Kenya. Bull. Environ. Contam. Toxicol. 49: 207-210.

Mugachia, J. C., L. Kanja \& T. E. Maitho, 1992b. Organochlorine pesticide residues in estuarine fish from the Athi River, Kenya. Bull. Environ. Contam. Toxicol. 49: 199-206.

Mugambi, J. M., L. Kanja, T. E. Maitho, J. U. Skaare \& P. Lokken, 1989. Organochlorine pesticide residues in domestic fowl ( $\mathrm{Gal}$ lus domesticus) eggs from central Kenya. J. Sci. Food. Agric. 48: 165-176.

Munga, D., 1990. DDT and endosulfan residues in four tropical fish species. In: Khan, M. R. \& H. J. Gijzen (eds), Environmental Pollution and its Management in Eastern Africa. Proceedings of a Symposium organised by the Faculty of Science, University of Dar es Salaam, 11-14th Sept. 1989.

Natural Resources Institute, 1991. NRI Pesticide Management Section. Training Manual for Pesticide Residue Analysis Vol. 2. Natural Resources Institute, U.K.

Pastor, D. J. Boix, V. Fernandez, \& J. Albaiges, 1996. Bioaccumulation of organochlorinated contaminants in three estuarine fish species (Mullus barbatus, Mugil cephalus and Decentrarcus labrax). Mar. Pollut. Bull. 32: 257-262.

PCPB, 1998. List of Pest Control Products Provisionally Registered by the Pest Control Products Board for use in Kenya. (Revised June, 1998). PCPB, Nairobi.

Tanabe, S., A. N. Subramanian, A. Ramesh, P. L. Kumaran, N. Miyazaki \& R. Tatsukawa, 1993. Persistent organochlorine residues in dolphins from the Bay of Benghal, south India. Mar. Pollut. Bull. 26: 311-316.

Wandiga, S. O., 1996. Organochlorine pesticides: curse or blessing in tropical agriculture? In: Wandiga, S. O. \& N. L. Abuodha (eds), Environment and Development in Kenya. Research Papers Presented at Academy Public Lecture Series. Kenya National Academy of Sciences, Nairobi.

UNEP, 1993. United Nations Environment Programme Environmental Data Report 1993-94. Blackwell Publishers, Oxford. 